\title{
External alternatives, job stress on job satisfaction and employee turnover intention
}

\author{
Ramlawati $^{a^{*}}$, Eva Trisnawati ${ }^{\mathrm{b}}$, Nurfatwa Andriani Yasin ${ }^{\mathrm{c}}$ and Kurniawaty
}

${ }^{a}$ Universitas Muslim Indonesia, Indonesia

${ }^{b}$ Universitas Teknologi Sulawesi, Indonesia

'Sekolah Tinggi Ilmu Ekonomi Tri Dharma Nusantara, Indonesia

\section{H R O N I C L E}

\section{Article history:}

Received: June 20, 2020

Received in revised format:

August 302020

Accepted: September 15, 2020

Available online:

September 15, 2020

Keywords:

External Alternatives

Job Stress

Job Satisfaction

Turnover Intention

\section{A B S T R A C T}

The purpose of this study was to determine the alternative external influence and job stress on employee satisfaction and to determine the effects of the alternative external influence, job satisfaction job stress on Turnover Intention on employees of PT Bank Mandiri Regional X South Sulawesi. Respondents in this study were 100 people. The analysis model used to determine the effect between variables was a structural model with the Partial Least Square (PLS) approach. The results show that external alternatives had a significant effect on job satisfaction, stress had no significant effect on job satisfaction, external alternatives had a significant effect on turnover intention, stress had no significant effect on turnover intention, and finally, job satisfaction had a significant effect on turnover intention. To reduce turnover intention, it is better to reduce employee access to information on outside market opportunities. Job market conditions outside the company had a stronger effect on turnover intention than the job satisfaction felt by Bank Mandiri employees and to increase employee job satisfaction efforts are needed to reduce stress in the form of reducing work overload, reducing conflict, giving proper responsibilities and improving development policies.

\section{Introduction}

Employees are an important asset for the company in carrying out company operations. The company must be able to retain its best employees so that they do not leave or move to join other companies. The reality is that there are still high levels of employees who decide to leave and move to another company. Turnover risks the loss of potential employees for the company, especially turnover caused by the employee's own desire (voluntary turnover). Employee turnover or employee turnover from the organization is an important phenomenon for the sustainability of an organization. If the turnover is high, the company will recruit to fill or replace employees who leave the company. Such conditions will result in higher investment in human resources, namely the high cost of investment and employee development. Apart from experiencing losses in terms of cost and time, turnover can also affect the continuity of the company's production operations. The success of a company in achieving common goals cannot be separated from a high level of concentration for all parts. Trevor (2001) states that a high turnover rate will have negative implications for the company and become a problem that must be solved by the company. This is supported by Ali and Baloch $(2008,2010)$ who state that high turnover results in high training costs, low enthusiasm for work, pressure on employees, and loss of human resources. The increasing number of turnovers will increase the cost for the company to recruit and conduct training for new employees to replace employees who leave so that the company is unable to achieve maximum efficiency. Some people believe that turnover intention is the level of desire to leave the company. There are many reasons for his desire to move (turnover intention), including the desire to get a better job. Among the factors causing the company's employees' desire to leave the workplace are external alternatives, work environment, stress, and job satisfaction.

* Corresponding author.

E-mail address: ramlawatyr0@gmail.com (Ramlawati) 
According to Hellman (1997), employee turnover can be triggered by many factors, but job satisfaction has been consistently identified as the main predictor. While dissatisfaction occurs when an employee has the thought of leaving his job since by leaving his job, the employee hopes to get another job that can provide better job satisfaction (Richardson \& Ardana, 2007). Mobley (1977) states that a lack of job satisfaction leads to thinking about quitting work, which leads to the search for alternative jobs, which can then lead to an intention to quit, or vice versa, which in turn can result in actual turnover. In the long term, employees who cannot withstand work stress will no longer be able to work. Employees who experience excessive work stress have implications for voluntary turnover. So, it can be stated that if employees feel low job satisfaction, high work stress, the employee will decide to leave an organization.

In July 2018, the UGM Engineering Career Center conducted a poll on 726 respondents regarding the reasons for the respondents choosing to resign or leave the organization, and the results of the poll stated that $22.4 \%$ chose their reason for resigning because of salary and facilities, $22.3 \%$ because of an unpromising career path, $13.6 \%$ due to a non-conducive work environment, $13.3 \%$ because of getting a more attractive offer, $10.7 \%$ because of a non-conformity with the system or organizational culture, $8.3 \%$ because of excessive work pressure, $6.1 \%$ because there is no challenge, and as many as $1.2 \%$ due to lack of social appreciation (ECC UGM in Careernews, 2012). This has also become a phenomenon in the banking industry, CEO of Standard Chartered Bank, Aaker (2011) stated that the biggest challenge in the banking world is human resources. This challenge requires banks to recruit qualified people and maintain them with some training (Aaker, 2011). Based on these cases, turnover in banking companies is still high since it has exceeded the percentage, which is more than $10 \%$. According to Gillis, 1994 (in Setiawan, 2018) employee turnover is said to be normal in the range of 5\% - 10\% per year, and is high if it is more than $10 \%$ per year. Furthermore, in the banking industry, particularly Bank Mandiri Regional X Sulawesi-Maluku, this is no exception.

\subsection{Research Problems}

1. Do external alternatives and job stress affect job satisfaction?

2. Are external alternatives and job satisfaction stress affect Turnover Intention?

\section{Literature review}

\subsection{Turnover}

Turnover is defined as the stopping an employee from working voluntarily. According to Zeffane (2003) there are several factors that influence turnover, including external factors such as intelligence, attitudes, past, types gender, interests, age, and length of work. According to Mathis and Jackson (2011), turnover is related to job satisfaction and organizational commitment. Turnover is the process by which employees leave the organization and must be replaced immediately. This is one of the biggest losses that a company will experience when many employees leave the company, especially those who leave are potential employees. Simamora (2004) defines turnover as voluntary separation by an employee from the organization. According to Cascio (1987), turnover is the permanent cessation of a work relationship between an organization and its employees or a separation between an organization and workers, whereas Novliadi (2007) defines the turnover phenomenon as the movement of labor to and from an organization. Furthermore, Handoko (2012) states that turnover is the departure of employees from the company to work for other companies. Mobley (in Susanti, 2008), an expert in the issue of employee turnover, provides a limit on turnover as an individual cessation of members of an organization accompanied by financial rewards by the organization concerned.

\subsection{Job satisfaction}

According to Mathis and Jackson (2011), job satisfaction is a positive emotional state from evaluating a person's work experience. Job dissatisfaction arises when these expectations are not met. Job satisfaction has many dimensions, in general, it is satisfaction in the job itself, salary, recognition, the relationship between supervisors and workers, and opportunities for advancement. This job satisfaction indicator can be measured by discipline, work morale, and small labor turnover, so that the employee's job satisfaction is relatively good, but on the other hand, if the discipline, work morale and labor turnover are large, then the employees' job satisfaction at the company is considered to be less. Robbins (1994) argues that job satisfaction is a general attitude of an individual towards his job. Work requires interaction with colleagues and superiors, following organizational rules and policies, meeting turnover intention standards, living in work conditions that are often less than ideal, and other similar things. This means the assessment (assessment) of an employee of his satisfaction or dissatisfaction with his job. Based on these definitions, it can be said that employee job satisfaction is the attitude of employees to how they view their work. Employee satisfaction can provide several benefits, including creating a harmonious relationship between the company and employees.

\subsection{Job Stress}

According to Greenberg et al. (1993), stress is a pattern of emotions and physiological reactions that occur in response to demands from within or outside the organization, and according to Robbins (19940 stress is a dynamic condition in which individuals face opportunities, constraints or demands related to what is very important, wants and whose results are perceived 
as uncertain but important. The National Institute of Occupational Safety and Health (NIOSH), (2008) defines work stress as physical and emotional hazards that occur as job needs that are incompatible with individual abilities, resources, and needs. Job stress arises because environmental demands and responses of each individual in dealing with them can be different. As a result of this work stress, people become nervous, experience chronic anxiety, increase emotional tension, thought processes and changes in individual physical conditions. Based on some of the definitions above, it can be concluded that work stress is a response given to a situation in the work environment that has a negative impact on employees and suppresses the lives of employees so as to form a change in employees both physiologically, psychologically and behaviorally.

\subsection{External Alternative}

The role played by perceived alternative employment opportunities is less clear. Some authors are of the view that job search and alternative job opportunities is the one that is taken because of job dissatisfaction (Hulin et al., 1985). Mobley (1978) theorizes a model in which he includes several important variables that assess employees' perceptions of alternative job opportunities and interactions with the external environment. Perceived alternative job opportunities have a direct and indirect impact on the intention to quit through job dissatisfaction (Griffeth \& Hom, 1988). Perceptions and expectations of alternative employment opportunities are also influenced by the labor market in general. The intention to remain in the organization is related to perceived alternative job opportunities and job satisfaction. When employees see more alternative employment opportunities and accept offers from other employers, they make a cost-benefit comparison between their current job and the alternative job (Mobley, 1977; Price, 2001). An employee may find confidence or hopelessness when looking for a job, that confidence or discouragement can be evaluated by certain events that imply success or failure in the job search, such as the number of job offers and frequency of interviews. These factors influence employees' perceptions of whether their job search will ultimately be successful or not (Laker, 2011). When employees will see low alternative job opportunities, their job satisfaction will increase but when they will see high alternative job opportunities, their job satisfaction will decrease.

Organizations that genuinely wish to retain and attract competent personnel seek to satisfy their workers by treating them very fairly in the context of distributive justice, procedural justice and interactional justice. Several studies have been conducted to find internal factors that can affect employee job satisfaction with managerial implications, but even so there are several external factors that are not under management control, but can reduce employee satisfaction with current jobs (Mushtaq et al., 2019). Focus should be given to these external factors, namely, perceived alternative job opportunities, which can affect employee job satisfaction.

\subsection{Conceptual framework}

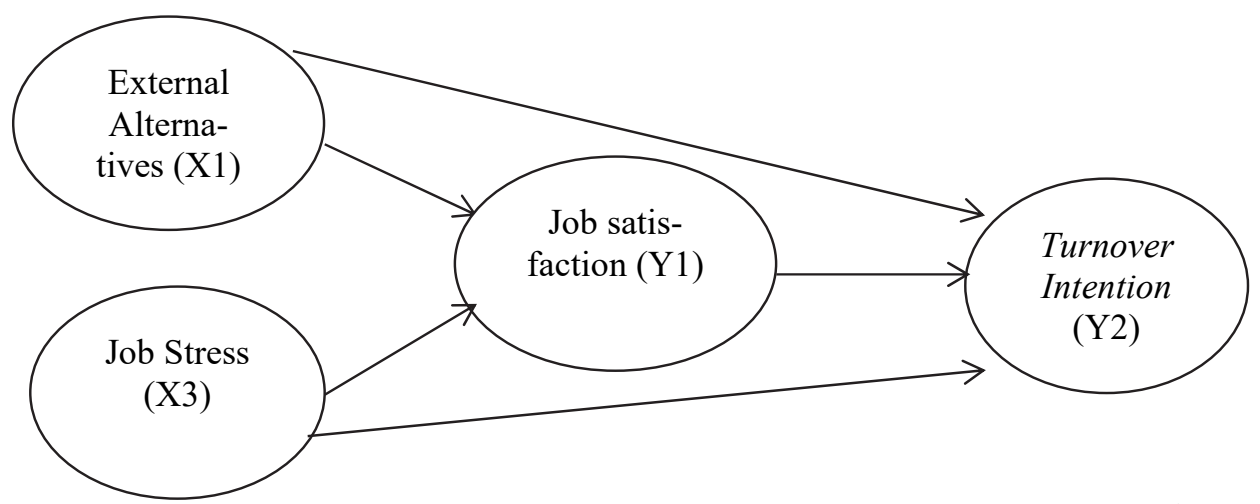

Fig. 1. Concept Framework

\section{Research methods}

\subsection{Research Location}

The location of this research is located in Makassar City at Bank Mandiri Regional X Sulawesi-Maluku, in charge of 8 Sulawesi-Maluku Provinces with 6 Business Areas namely Manado, Palu, Makassar Kartini, Kendari, Parepare, and Makassar Sam Ratulangi. This study took the object of Bank Mandiri Regional X Sulawesi-Maluku in Makassar City.

\subsection{Population and Sample}

The population in this study were all employees of Bank Mandiri Regional X Sulawesi-Maluku Makassar Kartini Business Area and Makassar Sam Ratulangi Business Area as many as 662 people. Furthermore, we calculate the number of samples using probability sampling with purposive random sampling method. 
Table 1

Employee Qualifications

\begin{tabular}{|c|c|c|c|c|}
\hline \multirow[t]{2}{*}{ No. } & \multirow[t]{2}{*}{ Level } & \multicolumn{2}{|c|}{ Business Area } & \multirow[t]{2}{*}{ Total } \\
\hline & & Makassar Kartini & Makassar Sam Ratulangi & \\
\hline 1. & Head \& Manager and Officer (Leadership Level) & $(107 / 662) \times 100=16$ & $(64 / 662) \times 100=10$ & 26 \\
\hline 2. & Implementers / ordinary employees (Implementer / employee level) & $(323 / 662) \times 100=49$ & $(168 / 662) \times 100=25$ & 74 \\
\hline & Total & 65 & 35 & 100 \\
\hline
\end{tabular}

\subsection{Analysis Method}

In this study data analysis is by using the Partial Least Square (PLS) approach. PLS is a Structural Equation Modeling (SEM) equation model based on components or variants. According to Ghozali (2006), PLS is an alternative approach that shifts from a covariant-based SEM approach to variant-based. First, the model determines the relationship between latent variables (structural model). Second, the outer model determines the relationship between latent variables and measurement model. Third, the weight relationship is where the value of the latent variable case can be estimated (Yasin et al., 2019)

\section{Research result}

\subsection{Measurement Model (Outer Model)}

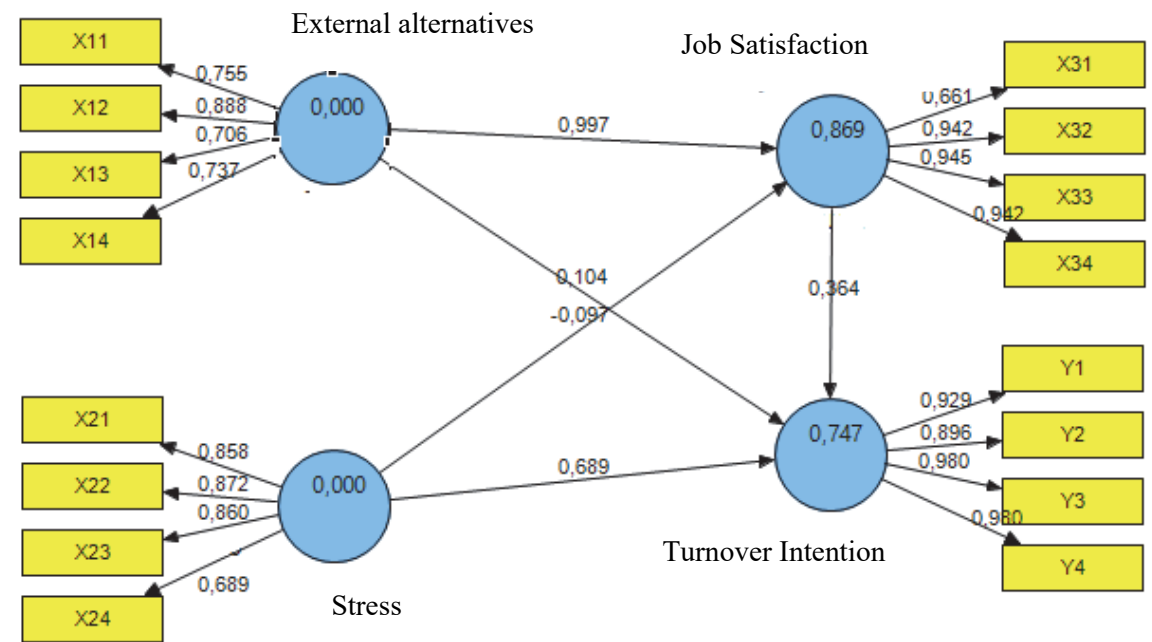

Fig. 2. SEM-PLS Measurement Model (Outer Model)

Table 2

Outher Loadings (Mean, STDEV, T-Value)

\begin{tabular}{|c|c|c|c|c|}
\hline & $\begin{array}{c}\text { Original Sample } \\
\text { (O) }\end{array}$ & Sample Mean (M) & $\begin{array}{c}\text { Standard Devia- } \\
\text { tion (STDEV) }\end{array}$ & $\begin{array}{c}\text { T Statistics } \\
(\mid \text { O/STERR } \mid)\end{array}$ \\
\hline Labor market opportunities (X1.1) & 0,755440 & 0,758019 & 0,038760 & 19,490311 \\
\hline Company appeal beyond (X1.2) & 0,887517 & 0,887038 & 0,023315 & 38,066312 \\
\hline Competency suitability (X1.3) & 0,705889 & 0,708728 & 0,066980 & 10,538734 \\
\hline Availability of jobs (X1.4) & 0,737403 & 0,729866 & 0,064338 & 11,461405 \\
\hline Overload (X2.1) & 0,857723 & 0,854934 & 0,035283 & 24,309617 \\
\hline Conflict (X2.2) & 0,871998 & 0,866896 & 0,040847 & 21,347801 \\
\hline Responsible (X2.3) & 0,860344 & 0,861706 & 0,025748 & 33,413765 \\
\hline Career development (X2.4) & 0,689283 & 0,689103 & 0,075971 & 9,519018 \\
\hline Appreciation (Y1.1) & 0,661208 & 0,657937 & 0,073454 & 9,001708 \\
\hline Well-being (Y1.2) & 0,942338 & 0,943182 & 0,013854 & 68,017625 \\
\hline The work itself (Y1.3) & 0,945027 & 0,943227 & 0,013674 & 69,112376 \\
\hline Supervision (Y1.4) & 0,942338 & 0,943182 & 0,013854 & 68,017625 \\
\hline Perception of ease of changing jobs (Y2.1) & 0,929061 & 0,929985 & 0,021602 & 43,008512 \\
\hline Job search efforts (Y2.2) & 0,895755 & 0,896477 & 0,029550 & 30,312945 \\
\hline An unexpected job offer (Y2.3) & 0,755440 & 0,758019 & 0,038760 & 182,158753 \\
\hline Income ratio (Y2.4) & 0,887517 & 0,887038 & 0,023315 & 182,158753 \\
\hline
\end{tabular}


Table 3

R-Square and Cronbachs Alpha

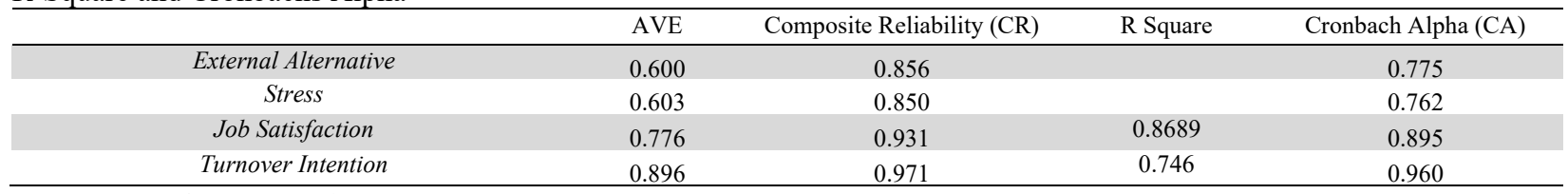

Source: PLS data processing (2020)

Discriminant reliability (AVE), Cronbach alpha (CA), and composite composites (CR) were measured. The criterion states that if the discriminant reliability (AVE) is greater than 0.5 , Cronbach alpha is greater than 0.6 and the composite reliability is greater than 0.7 , the construct is declared reliable. The reliability test shows (Table 3 ) that all latent constructs have AVE values greater than $0.5, \mathrm{CA}$ values greater than 0.6 , and $\mathrm{CR}$ values greater than 0.7 . Therefore, based on the reliability criteria, all items can be declared reliable in measuring latent variables. R-square model of alternative external measurement, stress, job satisfaction and turnover intention is 0.746 or $74.6 \%$. which means that the influence of alternative external variables, stress, job satisfaction on turnover intention is $74.6 \%$.

Table 4

Path Coefficients (Mean, STDEV, T-Values)

\begin{tabular}{cccccc}
\hline & $\begin{array}{c}\text { Original Sample } \\
(\mathbf{O})\end{array}$ & $\begin{array}{c}\text { Sample Mean } \\
(\mathbf{M})\end{array}$ & $\begin{array}{c}\text { Standard De- } \\
\text { viation } \\
(\mathbf{S T D E V})\end{array}$ & $\begin{array}{c}\text { T Statistics } \\
(|\mathbf{O} / \mathbf{S T D E V}|)\end{array}$ & $\begin{array}{c}\text { Information } \\
\text { External Alternative } \rightarrow \text { Job Satisfaction }\end{array}$ \\
$\begin{array}{c}\text { Stress } \rightarrow \text { Job Satisfaction } \\
\text { External Alternative } \rightarrow \text { Turnover Intention }\end{array}$ & $-0,997486$ & 1,000753 & 0,046694 & 21.362 & significant \\
$\quad$ Stress $\rightarrow$ Turnover Intention & 0,104372 & $-0,103341$ & 0,072324 & 1.347 & No significant \\
Job Satisfaction $\rightarrow$ Turnover Intention & 0,688731 & $-0,092550$ & 0,209948 & 0.497 & significant \\
\hline & 0,364069 & 0,686559 & 0,087281 & 1.891 & No Significant \\
\hline
\end{tabular}

The next test is hypothesis testing and determining the significance of the effect of exogenous variables on endogenous variables. SEM-PLS explains that the hypothesis measures the significance by comparing the T-table and T-statistic values. If the $\mathrm{T}$ count statistic is higher than the T-table value, then the hypothesis is accepted. The 95 percent (or $5 \%$; <0.05) confidence level for the two-tailed hypothesis is $>1.96$.

Table 5 examines the following hypotheses:

1. External Alternative has a significant effect on job satisfaction.

2. Stress has no significant effect on job satisfaction.

3. External Alternative has a significant effect on Turnover Intention.

4. Stress has no significant effect on Turnover Intention.

5. Job satisfaction has a significant effect on Turnover Intention.

\section{Discussion}

\subsection{External alternatives have a significant effect on job satisfaction and stress has no significant effect on job satisfaction}

It is interesting to note that when satisfied employees feel that there are many alternative job opportunities in the market and they can get a better job whenever they leave their current job, they become dissatisfied with their current job. But when employees feel that the market is saturated and it is very difficult to find job opportunities, they become more satisfied with their current jobs. This finding is consistent with research that found that job market conditions have an impact on employee job satisfaction (Gerhart, 1990). Lambert, Hogan and Barton (2001) found that job satisfaction significantly affects the external availability of existing job alternatives and the turnover rate. Employees who work in accordance with their competencies, skills and abilities will have an impact on improving the quality of optimal work results which will lead to increased employee performance. Good employee performance will synergize with satisfying work performance. Good employee performance will synergize with satisfying work performance. The reward indicator from the job satisfaction variable is the support provided by leaders and colleagues in the form of a need for respect and recognition of their work performance. The more appropriate the employee's competence with his current job, the higher the award received by the employee through the achievement of work performance so that the tendency for employee job satisfaction is also higher (Spector, 1985). Bank employees who have good skills and experience have a good level of satisfaction with their work, but the options and job 
offer outside are also increasing because reliable employees like this are much needed by large companies, where these companies are able to provide possible welfare. higher than the level of welfare they get at Bank Mandiri. The large number of job vacancies in big cities is a driving factor why it is very easy for employees to leave their jobs and move to other jobs, especially when they have good competencies, which makes them more confident that it will be easy to get a job outside the company where they are currently working. This is why in this study External Alternative has a significant effect on job satisfaction.

Then in this study it was found that stress has a negative and insignificant effect on job satisfaction. This means that the less stress experienced by an independent bank employee, the more satisfied the employee is with his job. Bank Mandiri employees agree that work stress creates a physical and psychological imbalance that affects the emotions, thought processes, and conditions of an employee, as a result there is an imbalance between employee personality characteristics and job characteristics so that it can interfere with their work performance. Empirical facts show that based on the results of pre-survey research interviews with the Officer of the Human Capital Talent Development Division of Bank Mandiri Regional X Sulawesi-Maluku, Prayuda and several random Bank Mandiri employees, it is known that one of the causes of the problem of Bank Mandiri employee dissatisfaction is the level of employee stress. high levels of work due to the high workload in the banking industry, particularly at Bank Mandiri. Stress arises when employees are unable to meet job demands, conflicts occur, it is unclear what job responsibilities are or the amount of responsibilities they carry, lack of time to complete tasks caused by overload, careers that don't go up, all of that trigger stress on employees at work. The same result was also found by Trivellas et al. (2013). Work stress related to conflict and heavy workload has been shown to negatively affect all dimensions of job satisfaction (physical environment and career opportunities, management style and job enrichment, and reward and job security).

\subsection{External Alternatives have no significant effect on Turnover Intention, Stress has a significant effect on Turnover Intention and Job satisfaction has a significant effect on Turnover Intention}

External alternatives have a positive and significant influence on turnover intention. This means that employees' high perceptions of external alternatives have contributed to the increase in employee turnover intention for Bank Mandiri Regional X Sulawesi-Maluku in Makassar City. These findings are consistent with social interdependence theory, that when externals are perceived as many job alternatives, employees tend to leave the company voluntarily and when external job alternatives are scarce, employees are more likely to be less involved in actual turnover. The role of perceptions about the availability of job alternatives through the labor market in determining employee turnover behavior is a prominent issue in understanding how employees respond to labor market fluctuations. This issue is relevant to the theory of social interdependence which states that when the labor market provides many external job alternatives, it will increasingly provide employees with more job alternative options and can result in job changes (Hulin, Roznowski, \& Hachiya 1985), rather than when the job market offers little. job alternatives so that employees have limited space in choosing job alternatives which results in a low probability of turnover (Gerhart, 1990). Employee interest in other companies outside the workplace has a consequence on increasing employee perceptions of alternative external jobs outside the organization so that when there are other attractive job offers it will cause a desire to leave the organization. An unexpected job offer means that there is another job opportunity outside the workplace without any prior intention. The more attractive job offers come unexpectedly, the higher the tendency for the intensity to leave because employees have a high perception of external job alternatives through opportunities in labor market conditions triggered by the large attractiveness of companies outside the organization.

Table 4 shows that job stress has a positive but insignificant effect on turnover intention. This means that high work stress does not necessarily contribute significantly to the increase in turnover intention of Bank Mandiri Regional X SulawesiMaluku employees in Makassar City. The insignificance of an increase in work stress on an increase in turnover intention in this study shows that even though employees have a high level of stress due to work pressure, this does not necessarily mean that employees have the desire to leave Bank Mandiri. This is because they are bound by various work rules that have been set by the internal management of Bank Mandiri and must be obeyed by all employees, so the work must still be completed even though employees are in stressful conditions because completing work is the obligation of every employee. The high workload of employees at Bank Mandiri can indeed be a trigger for work stress but the work stress experienced by Bank Mandiri employees is offset by a high level of welfare. The income or salary of Bank Mandiri employees is quite high when compared to the income ratios of other companies in similar industries (Prayuda, 2018). So even though the employee load is high which results in job stress, but because of the equilibrium of the employee's perceived welfare, it causes turnover intention to increase but not significantly. Work stress felt by employees has no significant effect on increasing turnover intention because this stress is more directed at positive stress which is considered not to interfere with employee performance and is instead used as motivation to further improve their work performance. The greater the effort to find work outside the organization, the higher the tendency for the intensity to leave the organization, which is due to the high work stress of employees which is triggered by the many conflicts between the desire for the role concerned and the work being done. Thus it can be said that work stress has a positive but insignificant effect on turnover intention. This means that reducing turnover intention is not necessarily done through efforts to reduce work stress in the form of reducing work overload, but by reducing conflict, assigning appropriate responsibilities, and improving career development policies for Bank Mandiri employees. 
The results of the study indicate that job satisfaction has a positive and significant effect on turnover intention. This means that high employee job satisfaction contributes to an increase in the turnover intention of Bank Mandiri Regional X SulawesiMaluku employees in Makassar City. This finding is relevant to the findings of Dardar et al. (2012) which states that job satisfaction is only one of the reasons for various causes of turnover intention problems such as job levels or job market opportunities to get other job opportunities outside the company. When satisfied employees feel that there are many alternative job opportunities in the market and they can get a better job if they leave their current job, they become dissatisfied with their current job. But when employees feel that the market is saturated and it is very difficult to find job opportunities, they become more satisfied with their current jobs. This finding is consistent with research that found that job market conditions have an impact on employee job satisfaction (Gerhart, 1990). This means that the high job satisfaction felt by employees is not able to reduce turnover intention because employees' perceptions of job market opportunities to get other job opportunities outside of Bank Mandiri are also high. Thus, the effect of market opportunities in the sense of obtaining job opportunities outside the company is higher than the effect of satisfaction on turnover. So, based on the findings above, it can be concluded that job satisfaction has a positive and significant effect on turnover intention which can be logically accepted (rationally).

\section{Conclusion}

1. External alternatives have a significant effect on job satisfaction and turnover intention. This means that external alternatives can be used as an instrument to influence satisfaction and turnover intention. So in order to increase job satisfaction and / or reduce turnover intention, Bank Mandiri must reduce access to information on alternative jobs outside of Bank Mandiri.

2. Job stress has a negative effect on job satisfaction. This means that increasing employee job satisfaction can be done through efforts to reduce stress in the form of reducing work overload, reducing conflict, assigning appropriate responsibilities and improving career development policies for Bank Mandiri employees.

3. Job satisfaction has a positive and significant effect on turnover intention. The positive influence between job satisfaction and turnover intention is influenced by opportunities in job market conditions. This means that reducing turnover intention does not have to be done through efforts to reduce job satisfaction but rather reduces employee access to information on outside market opportunities. Job market conditions outside the company have a stronger effect on turnover intention than on the job satisfaction felt by Bank Mandiri employees.

\section{References}

Aaker (2011). Standard Chartered Bank targets growth. Ali, N., \& Baloch, Q. B. (2008). Impact of job satisfaction on turnover intention: An empirical evidence. Journal of Managerial Sciences, 2(1), 23-41.

Ali, N., \& Baloch, Q. B. (2010). Job satisfaction and employee turnover intention (Case study of NWFP Pakistan based banking sector). Interdisciplinary Journal of Contemporary Research Business, 2(5), 39-66.

Cascio, W.F. (1987). Applied Psychology in Personnel Management ( $3^{\text {rd }}$.ed). New Jersey: Prentice-Hall Inc

Dardar, A. H. A., Jusoh, A., \& Rasli, A. (2012). The impact of job training, job satisfaction and alternative job opportunities on job turnover in Libyan oil companies. Procedia-Social and Behavioral Sciences, 40, 389-394.

Gerhart, B. (1990). Voluntary turnover and alternative job opportunities. Journal of Applied Psychology, 75(5), 467-476. Greenberg, J., Baron, R. A., \& Grover, R. A. (1993). Behavior in organizations: Understanding and managing the human side of work.

Griffeth, R. W., \& Hom, P. W. (1988). A comparison of different conceptualizations of perceived alternatives in turnover research. Journal of Organizational Behavior, 9(2), 103-111.

Handoko, H. T. (2012). Manajemen Personalia dan Sumber Daya Manusia. BPFE - UGM, Yogyakarta

Hellman, C.M. (1997). Job Satisfaction and Intent to Leaver. The Journal of Social Psychology, 137(6), 677-689.

Hulin, C. L., Roznowski, M., \& Hachiya, D. (1985). Alternative opportunities and withdrawal decisions: Empirical and theoretical discrepancies and an integration. Psychological Bulletin, 97(2), 233 -250.

Laker, D.R. (2011). Job search, perceptions of alternative employment and turnover. Journal of Applied Business Research, $7(1), 6-15$.

Lambert, E.G., Hogan, N.L., \& Barton, S.M. (2001). The impact of job satisfaction on turnover intention: A test of a structural measurement model using a national sample of Wworkers. The Social Science Journal, 38, 233-250.

Mathis, R. L., \& Jackson, J.H. (2011). Manajemen Sumber Daya Manusia. Salemba Empat, Jakarta.

Mobley, W. H. (1977). Intermediate linkages in the relationship between job satisfaction and employee turnover. Journal of Applied Psychology, 62(2), 237.

Mobley, W., Horner, O. \& Hollingsworth, A. (1978). An evaluation of precursors of hospital employee Turnover. Journal of Applied Psychology, 63(4), 408-414

Mushtaq, A., Amjad, M. S., Bilal, B., \& Saeed, M. M. (2014). The Moderating Effect of Perceived Alternative Job Opportunities between Organizational Justice and Job Satisfaction: Evidence from Developing Countries. The Journal of Business Economics and Environmental Studies, 4(1), 5-13. 
Novliadi, F. (2007). Intensi Turnover Karyawan Ditinjau dari Budaya Perusahaan dan Kepuasan Kerja. Medan: Universitas Sumatera Utara.

Trivellas, P., Reklitis, P., \& Platis, C. (2013). The effect of job related stress on employees' satisfaction: A survey in health care. Procedia-social and behavioral sciences, 73, 718-726.

Prayuda. (2018). Officer Divisi Human Capital Talent Development Bank Mandiri Regional X Sulawesi-Maluku

Richardson, H.A., \& Ardana, R.K. (2007). Perceived Organizational Support's and Role In Stressors-Strain Relationship. Journal of Managerial Physichology, 23(7), 789-810.

Robbins, S. P. (1994). Human resource management: concepts and practices. Wiley.

Setiawan, R. (2018). Pengaruh Job Involvement Dan Job Characteristik Terhadap Turnover Intention Pada PT. Mustika Lestari Indonesia, Journal of AGORA, 6(2).

Simamora, H. (2004). Manajemen Sumber Daya Manusia. Edisi Ketiga. Yogyakarta: Sekolah Tinggi Ilmu Ekonomi YKPN

Spector, P.E. (1985). Job satisfaction: Application, Assessment, Cause and Consequences. Thousand Oaks, CA: Sage Publications

Susanti, D.W. (2008). Hubungan Antara Efikasi Diri Dengan Intensi Turnover Pada Karyawan Bagian Service Direct PT. Trakindo Utama Balikpapan. Sarjana Psikologi pada Universitas Islam Indonesia Yogyakarta

Trevor, C. O. (2001). Interaction Among Actual Ease-of-Movement Determinants and Job Satisfaction in the Prediction of Voluntary Turnover. Academy of Management Journal, 44(4), 621-638.

Yasin, N. A., Ridjal, S., \& Jjufri, M. (2019). Human capital and entrepreneurship and their impact on the productivity of traditional craftsmen. Revista ESPACIOS, 40(4), 8-20.

Zeffane, R. (2003). Organizational Behavior A Global Perspective. Australia: John Wiley and Sons Australia Ltd.

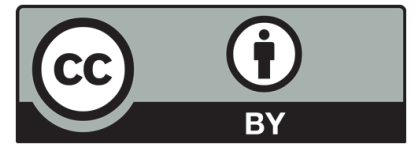

(C) 2020 by the authors; licensee Growing Science, Canada. This is an open access article distributed under the terms and conditions of the Creative Commons Attribution (CC-BY) license (http://creativecommons.org/licenses/by/4.0/). 